\title{
Public implementation of government programs for poverty alleviation: public sphere utilization in Brebes, Indonesia
}

\author{
Helpris Estaswara \\ Universitas Pancasila, Indonesia \\ the.estaswara@yahoo.com \\ Umar Halim \\ Universitas Pancasila, Indonesia \\ umarhalim@univpancasila.ac.id \\ Andi Faisal Bakti \\ Universitas Pancasila, Indonesia \\ Syarif Hidayatullah State Islamic University, Indonesia \\ amfabak@gmail.com
}

Anna Agustina

Universitas Pancasila, Indonesia

annaagustina@univpancasila.ac.id

Riza Darmaputra

Universitas Pancasila, Indonesia

rizadarmaputra@univpancasila.ac.id

Recibido: 1/8/2018 / Aceptado: 22/1/2019

doi:10.26439/contratexto2019.n031.3891

\begin{abstract}
Aвstract. The utilization of the public space and sphere is considered to be crucial for poverty alleviation. As the Brebes district in Indonesia has the largest percentage of poor people in Central Java (19.14\%), the district head has established a Poverty Alleviation Section to identify the underlying causes as well as some possible solutions. Research shows that, by opening channels of discussion and sharing ideas inside the public sphere as well as by optimizing the public space, the population of Brebes will be able to change all aspects of life, including seizing new economic opportunities. The framework
\end{abstract}


of this research used the eight elements of the public sphere along with the active reception model of communication and cross-road communication. The data used was gathered through in-depth observation, focus group discussions, together with both open-ended and unstructured interviews conducted between June 2017 and April 2018. Document and literature reviews, which contributed to support the analysis of this paper, were compiled using library work, fieldwork, and Internet research.

Keywords: poverty alleviation / public sphere / public space

\section{Implementación de programas gubernamentales para el alivio de la pobreza: utilización de la esfera pública en Brebes, Indonesia}

Resumen. La utilización del espacio y esfera públicos es considerada crucial en la reducción de la pobreza. Debido a que el distrito de Brebes en Indonesia tiene el mayor porcentaje de personas en situación de pobreza en Java Central (19,14 \%), la alcaldía ha establecido una Sección de Alivio de la Pobreza para identificar las causas subyacentes, así como las posibles soluciones. Las investigaciones muestran que, al abrir canales de discusión, compartir ideas en la esfera pública, así como optimizar el espacio público, la población de Brebes podrá efectuar un cambio en todos los aspectos de su vida, incluyendo el aprovechamiento de nuevas oportunidades económicas. La presente investigación está enmarcada en los ocho elementos de la esfera pública, junto con el modelo de recepción activa de comunicación y el cruce comunicativo. La información utilizada se recopiló a través de la observación a profundidad, discusiones de grupos focales, y también entrevistas de preguntas abiertas y no estructuradas realizadas entre junio del 2017 y abril del 2018. Los documentos y literatura revisados que contribuyeron a sustentar el análisis de este artículo se compilaron por medio de trabajo de biblioteca, trabajo de campo y búsqueda en internet.

Palabras clave: alivio de la pobreza / esfera pública / espacio público 


\section{Introduction}

ccording to Nam and Pardo (2011), a smart city can be formed using
three components: technology, humans, and institutions (government).
Out of these components, human capital is the starting point in developing a smart city. Indeed, when using Information Technology (IT), people are driven by two factors, namely psychology or a mental factor on the one hand, and a social or cultural factor on the other hand (van Dijk, 2005). Thus, the formation of a smart city does not only rely on the ability of government institutions to build infrastructures and issue policies; it also relies on how well the public accepts IT.

As part of his definition of civil society, Janoski (1998, p. 12) mentions eight elements of the public sphere: political parties, associations, education, welfare state, self-help groups, media, health, and R \& D (research and development). However, this paper only deals with the first six spheres - with the last two being the object of a separate research - in particular to address poverty alleviation in the Brebes district, Indonesia. Since 2017, the Brebes regional government has been running several programs aimed at poverty alleviation, setting up a Poverty Alleviation Section within the district administration.

\section{Conceptual framework: on the concept of public sphere}

Civil society has at least four possible implementations: the first one is made up of the non-state sphere; the second one of capitalism and individualism; the third one of associations, and the last one of the private sphere. However, Thomas Janoski's (1998) theory is unique regarding his clear classification of civil society into four spheres - state, market, public, and private- where each sphere has the same function to ensure checks and balances for a truly civil society at the country level, as believed by Cohen and Arato (1992, p. 421-491) as well as Baiocchi, Heler, and Silva (2011). For Janoski, no civil society can exist without the involvement of these spheres. This last context of civil society will be the definition used in this paper.

Some of the abovementioned spheres overlap with other spheres: for example, a member of a political party who sits in parliament, consumer unions which are in business, and personal and family affairs which are covered in public media.

In addition, instead of touching on all four spheres, this paper will focus on the public sphere. For Janoski (1998), this sphere includes discourses of the abovementioned four spheres. Such opinion is supported by Aubin (2014), although he distinguishes it from public space: "While the public sphere is about discourse, the public space is about the course" (Aubin, 2014). We can also say that, if the 
public sphere deals with temporal and more abstract issues, the public space deals with spatial, more concrete, and physical things.

The space has also given rise to new concepts such as digital city, intelligent city, virtual city, ubiquitous city, information city (Ishida, 2017), with the latest being smart city (Ishida, 2017; Nam and Pardo, 2011). ICT (Information Communication Technology) has brought many changes not only to 'humans' but also to the 'space' in which humans interact. Changes in the human aspect have established new life structures such as an information society (Castells and Himanen, 2002; Mclver, 2004; Webster, 2006), a knowledge society (Mclver, 2004), and a network society (Castells, 2004; van Dijk, 2005).

A smart city is a city capable of exploiting the physical space by applying technology to build independent monitoring systems and self-response to complex social problems, including resource scarcity, and inadequate and poor infrastructures (Ishida, 2017). Washburn, Sindhu, Balaouras, Dines, Hayes, and Nelson (2010) define smart city as "the use of smart computing technologies to make the critical infrastructure components and services of a city - which include city administration, education, healthcare, public safety, real estate, transportation, and utilities - more intelligent, interconnected, and efficient."

The issue of poverty alleviation cannot be separated from the temporal, structural, and cultural causes on the one hand, and the spatial, negotiation, and creation on the other hand (Bakti, 2004; 2013). The active reception model of communication and development is important for the present analysis. All three models of communication will be examined in this paper.

\section{Methodology}

\section{Approach}

By using the eight elements of the public sphere and space for both data collection and data analysis of the Brebes government policies regarding poverty alleviation, data for this paper was gathered from the field between June 2017 and April 2018. We contacted the district head, whom we had first met in Jakarta during the UNESCO Chair holders' visit to the Taman Mini Indonesia Indah (TMII), a culture-based theme park of Indonesia, in the course of the cultural visit following the $6^{\text {th }}$ Annual Meeting of the Members of ORBICOM held in Jakarta in May 2017. ORBICOM leaders had exchanged ideas with this district head and department services heads. The UNESCO Chair on Communication and Sustainable Development (COSDEV) at Universitas Pancasila then chose the Brebes district for its case study. 
As the Millennium Development Goals (MDGs) had completed their 15-year mission, in 2015, the Sustainable Development Goals (SDGs) were set to continue the task of the MDGs. COSDEV is now committed to raising the 17 issues covered by the SDGs, including poverty alleviation, sustainable cities and communities, education, good health and well-being, gender equality, clean water, sanitation and energy, climate action, among others. However, as an empirical context, this paper only covers the first four issues and the focus of the Brebes district's head in 2018. Other issues will be directly addressed over the next four years (both the Brebes government and COSDEV researchers agreed to address all 17 issues one by one in the course of a five-year research program).

The action-situation approach is employed in this paper. According to Ostrom (2011, p. 11), "action situations are the social spaces where individuals interact, exchange goods and services, solve problems, dominate one another, or fight (among the many things that individuals do in action situations)." For him, "a major proportion of theoretical work stops at this level and takes the variables specifying the situation and the motivational and cognitive structure of an actor as givens. Analysis proceeds toward the prediction of the likely behavior of individuals in such a structure" (Ostrom, 2011, p. 11).

\section{Method}

In June 2017, we conducted a Focus Group Discussion (FGD) which included the district head along with all department services (dinas) heads. As researchers, we had framed the following questions: How can the public sphere and space be maximally utilized in order to pave the way to alleviate local poverty? In other words, how can the government solve this problem?

The objective of this paper is to analyze how useful the public sphere in Brebes is in maximizing the resources in that district. The public sphere is to be widely opened for the people to engage in finding solutions to poverty. The district head is struggling to find ways to alleviate poverty in Brebes, which accounts for $19.14 \%$ of its 1.9 million population, the highest rate in Central Java. Although 360,000 people are poor, Brebes is actually the largest district and has the largest paddy field area and production in the province. In fact, the district is the rice granary (lumbung padi) of Central Java.

In April 2018, a new FGD was conducted to cross check the information collected over both periods. In a triangulation procedure, both FGDs were coupled with in-depth interviews carried out in each department service. We then visited all department services, where not only the heads sat with us and answered our questions, but other subheads and staff members of each service were also 
involved. Our interviews were unstructured, and used open-ended questions and answers.

To complement these interviews, we also conducted field observations, where the activities of all six elements of the public sphere were taking place and various pieces of information could be directly accessed. In the course of this research, matters such as trips, visits, meals, and questions were continually dealt with the heads and staff members accompanying us.

Documents were collected from the staff members through the email and WhatsApp application used for this purpose. The decrees, task force reports, and instructions of the district heads, service heads, and subheads were collected to ensure that the written policies would be readily accessible for analysis.

Both primary and secondary sources regarding the Brebes history, the district background, and its status as well as the recent changes and development which have occurred in the district were gathered from the library and offices of the heads. Several works of previous researchers were also consulted to gain better understanding of the previous and current situations to determine the causes of poverty and the way to work towards its alleviation.

\section{Results}

\section{Political Parties}

The Brebes district is currently led by Mrs. Idza Priyanti (bupati, district head or regent) and Mr. Narjo (wakil bupati, district vice head), both elected in 2017. In that process, the Idza Priyanti-Narjo team won 39 (7 parties) out of 50 parliamentary seats (9 parties) and received $67.01 \%$ of the public votes, while its opponent, the Suswono-Mustaqin team, only supported by the Prosperous Justice Party (PKS) and the Gerindra Party, received 32.99\% of the votes.

During their electoral campaign, both Idza and Narjo focused on the poverty alleviation issue in the Brebes district. In fact, such issue was strongly underlined since Brebes has the highest poverty rate out of a total of 32 districts in the province of Central Java. To carry out its program, the Brebes government formed a new work section for poverty alleviation, which has been endorsed by the Legislative Council of the Brebes district. Based on Regulation No. 10/2016 on the "Duty, Function, and Description of the Structural Job Position of the Brebes District Device" ordered by the Brebes district head (peraturan bupati), the Poverty Prevention Division comes under the assistant secretary of the Government and Social Affairs Sector. 
The poverty alleviation issue in Brebes not only has the support of most political parties in the district but also of the central government, as the district has become a pilot project for an integrated poverty alleviation program conducted by this government and authorized by President Jokowi in June 2016. As a result, several cross-sectoral programs have been undertaken for poverty alleviation in Brebes, beginning with the program conducted by the Ministry of Agrarian Affairs and Spatial Planning aimed at providing land certificates for the poor.

The Ministry of Finance, along with the Bank of Indonesia (BI) and the Financial Services Authority (OJK), manages a credit distribution program for the poor (KUR). Meanwhile, the Ministry of Trade regulates the trade system of shallots in Brebes, considering that shallots are the main agricultural commodity in that district. Data shows that, out of the total population in Brebes, about $51.42 \%$ work in the agriculture sector, which contributes to $52.18 \%$ of the Brebes economy. Interestingly, Brebes supplies about $40 \%$ of the shallots bought nationally. Other data also shows that $50 \%$ of the poorest people in Brebes are farmers.

\section{Voluntary Association}

At the end of 2017 and beginning of 2018, the Farmers' Union (Gabungan Kelompok Petani - Gapoktan) held a demonstration in front of the General Logistics Agency (Bulog) and the Brebes district's office to protest against the drop in the price of shallots to IDR 3,000 (USD 0.22) per kilogram. The union demanded the stabilization of the price of shallots and the government eventually promised to purchase shallots from farmers at IDR 15,000 per kilogram. In addition to the Gapoktan, there are a number of other associations in the area. The 2018 data shows that 86 NGOs (Non-Governmental Organizations) and CSOs (Community Service Organizations) registered in the National and Political Unity Agency (Kesbangpol, the official registry for associations) are found in Brebes. Out of these, only about 20 are active. Additionally, the Brebes government provides a grant of IDR 15 million (approximately USD 1,200) per year for the empowerment of NGOs and CSOs. National NGOs and CSOs must obtain a decree (letter of decision) from the Ministry of Law and Human Rights (Kemenkumham, Kementerian Hukum dan Hak Asasi Manusia), which has been locally active since 2015, and a company registration letter (STL) in Brebes, while local NGOs and CSOs only require a notarized document, a certificate of domicile, and an STL. The Kesbangpol has a monthly work program related to political education, with agents travelling throughout all districts. In addition, it organizes yearly political education seminars where all Brebes NGOs and CSOs are invited. 
Concerning religious matters, and considering that the Brebes population is predominantly Muslim, the local Islamic Center organizes an aid program whereby its Zakat Collector Unit collects funds which are redistributed to the mustahiq (beneficiaries) in Brebes. While the Islamic Counseling Section in the Religious Affairs Office (KUA) generally addresses issues related to family, encouraging families to be sakinah, mawaddah, wa rahmah (at peace, affectionate, calm, and blessed in accordance with the Islamic teachings), every KUA in Brebes has 17 counselors and penghulu (religious persons in charge of marriages). However, lectures' and speeches' topics delivered in Brebes mosques mostly address spiritual but not development issues.

Regarding the right to demonstrate in public spaces, the NGOs or CBOs that wish to hold a demonstration must obtain a permit from the relevant Police Department and Office, and send a notification letter to the National Unity, Politics, and Community Protection Agency. In practice, all NGOs or CBOs that will hold a demonstration obtain a permit. However, permit applications are not always done in a formal way. Many demonstration permits are only obtained informally via SMS (Short Message Services). This situation happened to the relevant office (the office targeted for demonstrations) and to the National Unity, Politics, and Community Protection Agency. In the event of any disagreement between the Brebes government and the NGOs or CSOs, dialogue between the actors is generally promoted. If agreements are not reached through this process, NGOs or mass organizations organize demonstrations.

In addition to the Farmers' Union, the Fatayat NU group is engaged in children's protection and suppression of acts of violence. Data provided by the Women Empowerment and Child Protection Section records 101 cases of violence against children in Brebes in 2016, and 128 of such cases in 2017. Additionally, the Forum for Private School Teachers (Forum Guru Swasta - Forgusta) defends the welfare of the teachers in the regency. Forgusta has often conducted demonstrations, one of which disturbed traffic flow and requested reaudience to address teachers' low salaries in Brebes, which ranged from IDR 100,000 to 250,000 a month (about USD 7.5-20 a month). Forgusta conducted demonstrations not only at the Office of Education, Youth and Sports (Dindikpora, Dinas Pendidikan Pemuda dan Olah Raga) but also at the Brebes Level II Regional Office. Fighting for teachers' welfare is the concern not only of Forgusta but also of the National Amil Zakat Agency (Badan Amil Zakat Nasional - Baznas) in Brebes, which helps to apply for the certification of teachers still in a honorary status. Moreover, Baznas provides individuals with a monthly zakat (almsgiving), a complement taken from the total amount of IDR 27 million collected through the Almsgiving Collector Unit (Unit Pengumpul Zakat Assistance - UPZ) which helps about 60 civil servant 
and teachers. Today, according to the respondents, the population of Brebes still does not believe in distributing almsgiving through Baznas and prefers to use its own channels for that purpose. Such actions are implicit protests against the poor management of Baznas, where it is said funds do not go back to the community but are directly given to the Islamic Center. The Almsgiving Collector Institution (Lembaga Amil Zakat - LAZ) appeared later within the Islamic community without doing any coordination with the Ministry of Religious Affairs, thus it was unregistered.

\section{Welfare}

Most of the social assistance provided by the Brebes or central government is allocated to the reparation of inappropriate housing (RTLH). In fact, data shows that in 2017 the Brebes government disbursed IDR 5.8 billion (around USD 500,000) to repair 833 houses belonging to poor households. The RTLH program gives to each head of household (KK) a financial assistance of IDR 7 million (approximately USD 550): a smaller amount than that of the previous year which came to IDR 15 million (approximately USD 1,150). This situation reflects the increase in the number of households asking for assistance in 2017, as the total allocated sum remained the same. Based on 2016 data, the number of Brebes houses that were uninhabitable reached to 40,000 .

In 2018, the central government also provided a landslide disaster relief of 1.1 billion IRD to the Brebes community. Additionally, the Brebes government together with its Logistic Unit Bureau (Biro Unit Logistik - Bulog) distributed 1,799,150 kilograms of relief rice (Rastra) to eligible families (KPM), which consisted of about 180,000 inhabitants. According to this program, each family got $10 \mathrm{~kg}$ of rice each month between January and February 2018. From March to December 2018, KPM were entitled to receive non-cash food aid by having the Red and White Card (MerahPutih - KKS). Thus, 510 KPM received this card worth IDR 500,000 (about USD 38.5), which they could use to purchase goods in e-Waroeng or e-shop (Warung Gotong Royong Elektronik) and collect this sum through the BNI (Bank Negara Indonesia). The Red and White Card is part of the central government's a poverty alleviation program which replaced in 2016 the Effective Direct Cash Transfer (BTL) program. Brebes itself has 12 $e$-Waroeng. Going forward, the Brebes government plans to propose as many as 33 e-Waroeng. The Red and White Card program is a way to implement a noncash food aid as a form of acceleration strategy to meet the basic needs of the poor in accordance with the Presidential Decree No. RI. 63/2017 on "Non-cash food social assistance." 


\section{Self-Help Groups}

In Brebes, there are groups of people who help themselves by planting a mangrove. The mangrove forest that has been set up in the district has become one of the region's tourist attractions and provides a livelihood for local residents. The 2,000 to 3,000 visitors a week who visit this mangrove forest ultimately provide a new source of income for local residents who sell various foods and souvenirs.

Under the Market Regulation No. 1/2012, occasional markets open in Brebes every Sunday, providing business opportunities to 300 merchants for a minimal fee of IDR 5,000 (about USD 0.4) to the Islamic Center. On the other hand, the revenues provided by 27 traditional markets spread across 17 subdistricts in Brebes reach IDR 4.8 billion (about USD 34,000), where the funds are then managed by districts or villages, and are used for infrastructure maintenance. In addition to traditional markets, Brebes also has five supermarkets including a department store (Toko Serba Ada).

The many markets in Brebes are still not sufficient to accommodate all traders. As a result, many traders sell their wares on main roads near traditional markets from morning to noon, thus disturbing the traffic. Moreover, sidewalks and city parks are also used as trading places from the afternoon until the morning. There are also a number of semipermanent selling spots on sidewalks opened all day or all night. This situation comes as a result of an agreement signed between the Brebes government and the merchant's association which needed a place to sell.

\section{Media}

The media in Brebes is limited and generally dominated by the national mass media (12 television channels and 300 radio stations). Brebes has no local television, and there are only two public newspapers: Brebesnews.co and Brebes Daily. There are 14 radio stations in Brebes: two AM stations and 12 FM stations. The Brebes government manages the information about Brebes through the Brebeskab.go.id website. Some social media, including Facebook, used to serve as a medium of communication between the Brebes government and NGOs or CSOs, have been closed.

Various vertical conflicts on education and health have emerged between the local government and NGOs or CSOs representing the community, and have given rise to the cipok movement, which means moci and gepok (moci: drinking from a teapot and gepok: discussion) or drinking tea around a teapot while discussing different economic, social, political, and environmental issues in Brebes. This movement has been part of the Brebes culture since 2000 and the most effective communication medium in solving several social problems in Brebes. 
Interestingly, cipok is done in sidewalk tea shops which are opened from the afternoon until the morning. In fact, many of the teapot stalls are standing on the sidewalks of the town square, right in front of the office of the Brebes regent.

The government branch involved in moci is Kesbangpol, which uses this form of communication in its coordination efforts with NGOs or CSOs ahead of demonstrations. The police as well as the police chief often use moci with NGOs or CSOs to discuss the Brebes environmental security. Likewise, agricultural services officials are also often engaged in moci when the price of shallots is low, in order to listen to shallots farmers' aspirations and discuss solutions. Finally, the moci practice was started by the 12th Brebes district head, Mohammad Tadjudin Noor Aly, and followed by a number of subsequent district heads. Nevertheless, the current district head, a female, does not follow this practice as it goes against the role of women in the Javanese culture.

\section{Education}

In favor of education for the poor and anticipating demographic burst by 2030, the Brebes government spent IDR 18 billion (approximately USD 1.4 million) for the development of junior and senior high schools in 2017 in a program called School Operational Assistance (Bantuan Operasional Sekolah @ BOS), while the amount of the BOS funds allocated to elementary schools reached IDR 31.5 billion (approximately USD 2.5 million) in 2015. Although the implementation of the BOS program was a great help, funding for education in Brebes is still lacking. The BOS funds are an aid to meet operational needs but they are not enough. The BOS program provides private schools with a yearly funding of IDR 800,000 per student, while the ideal annual funding should reach IDR 1.5 million per student. Likewise, the yearly funding provided by the BOS program for junior high school reaches IDR 1 million per student, against an ideal amount of IDR 1.8 million per student. Similarly, to meet the basic operational needs of high schools, the BOS program allocates a mere IDR 1.4 million per student every year, whereas the annual funding needed is IDR 2.5 million per student. Although this shortfall has been mitigated by the district head's funding of an additional IDR 300,000 per student (about USD 23), it remains less than the ideal to meet the present needs. There are 888 primary schools in Brebes which are made up of 157,862 pupils, and 136 junior high schools which train 57,845 students.

The central government's regulations prohibit schools to charge education fees to parents. In fact, to help cover the shortage despite the combined BOS funds and district head's donations, schools should be allowed to ask for voluntary contributions from parents who can afford it, not forcing them to cover the cost of their children's education. However, if such donations are asked, some 
respondents believe that a number of NGOs would irresponsibly question the donations and, ultimately, teachers, school principals, and education offices would be afraid to collect the money. If schools use the word "dues," NGOs would translate this as schools using a loophole since fees are perceived to be a levy, thus making said schools liable to legal action. On the other hand, schools as well as many parents and people who want to help improve education consider such fees as voluntary donations. Interestingly, it is a fact that many students can afford it, as the motor vehicles they drive to school demonstrate. Ironically, because schools prohibit charging parking fees for motor vehicles, students eventually park in homes located in the vicinity of schools, where they are charged between IDR 1,000 and 2,000 a day.

Another consequence of the inadequacy of the BOS funds despite their combination with the district head's assistance is the low monthly salary of teachers, which amounts to around IDR 150,000 (about USD 12), whereas the minimum regional salary (UMR) applied in the Brebes district reaches IDR 1.4 million a month. Brebes hires 6,500 nonpermanent teachers (in public elementary schools, and junior and senior high schools) who struggle to live on this extremely low income by supplementing their revenues through other occupations. Similarly, as many as $70 \%$ of private school teachers (5,200 people) get monthly professional fees of IDR 150,000. The Brebes government finds it difficult to increase these teachers' wages since it is bound by a regulation limiting to $15 \%$ the percentage of the BOS funds set by the central government for this matter, and it is not authorized to receive additional funds from parents. The Brebes government is also handicapped by the fact that the central government has created a free nine-year compulsory education.

\section{Health}

The Islamic Student Association (HMI) and the FEBAL's Communications and Institutions Forum (FOCAL) in Brebes requested in 2017 hearings on the local government's health financing policy to the Brebes government and the district head's parliament. In Indonesia, a healthcare policy (Law No. 24/2011) was implemented through the Social Security Administering Body (Badan Pelayanan Jasa Sosial - BPJS Kesehatan). The government also issued a Healthy Indonesian Card (KIS) or BPJS Beneficiary Card (PBI) intended to provide free healthcare for the poor funded by the Brebes APBN and APBD (state and district budgets), while those who could afford it (the indicator was workers and employers) were also entitled to have a health insurance but paying dues. Data indicates that the number of PBIs in Brebes reached 1,248,000 in 2017, as against the official count of 338,000 poor people. As a result, the Brebes government had to spend IDR 10 billion a year 
(about USD 800,000) to cover public healthcare costs. The budget of the Development Planning Agency, Research, and Development Area (Bappelitbangda) amounted to only about IDR 1.5 billion (about USD 115,000), but eventually swelled to IDR 8.5 billion (about USD 650,000). This explains why HMI and FOKAL concluded that the calculation, if summed and adjusted with the Minister of Social Affairs Decree (Kepmensos) No. 146/HUK/2013 on "Stipulation of Criteria and Data Collection on Poor and Disadvantaged People," in fact means there are 50\% more Brebes residents who otherwise cannot afford it.

For its population of 2 million, Brebes has 38 community health clinics (Pusat Kesehatan Masyarakat - Puskesmas) and 60 satellite clinics (Puskesmas Pembantu). Each Puskesmas must handle 40,000 people. On the other hand, only 70 doctors (civil servants) work in Puskesmas and their satellites, together with 10 dentists who work in 38 Puskesmas. Interestingly, among the BPJS recipients, 1.2 million do not have an identity card (Population Identity Number - NIK), while 200,000 people who presently benefit from the BPJS program have an identity number which is different from the registered one. In addition, there are 12 public and private hospitals. Ten private units of Brebes public hospitals generally take part in the BPJS program, where the fees billed to patients are charged to the government budget. As a result, private hospitals only allocate $15 \%$ of their rooms to VIP classes and the rest to BPJS patients.

\section{Discussion}

Based on the various aspects that have been described above, the Brebes government has politically adopted a top-down model in alleviating poverty. This comes as a logical consequence of the district head's political promises made during the election periods to eradicate poverty in Brebes, the poorest district in Central Java. This is evidenced by the establishment of a Poverty Alleviation Section which is directly under the command of the district head. In that approach, the Brebes government website is a one-way media, as it is not interactive. Similarly, a number of social assistance programs have been initiated by the Brebes and central governments, and a top-down approach has been observed in the cooperatives and SME sector, where the district head was granted an award for the seriousness of her administration. In view of the above analysis, although many programs have been undertaken by the Brebes government, the poverty rate has not declined significantly in the last three years and Brebes has remained the poorest district in Central Java.

Many NGOs and CSOs in our analysis have championed the welfare of the population in the fields of education, health, and economics (e.g. points of sale and price of shallots): an indication that there are still problems in these areas. 
Such indicators also show that various poverty alleviation programs are not yet optimal. In the field of education, the government policy is unable to financially cope with the nine years of free education, as seen in Brebes, but no attempt has been made to improve the national policy on education, and funding remains insufficient in that area. In addition, discussions can be conducted with NGOs and CBOs on the issue of free education, in order to find solutions to policy changes by suggesting voluntary contributions from better-off parents. Furthermore, such measure could be enforced and implemented immediately to improve the welfare of teachers. Reaching an agreement between the Brebes government, NGOs, and CSOs in order to foster the welfare of teachers will become a starting point to a mutual understanding to address other educational issues in Brebes.

In fact, health policy is also not understood by most people in Brebes. Our analysis shows two categories of BPJS healthcare recipients, namely the needy, as shown on their health insurance card (BPJS), whose contributions are borne by the government, and those who cover their own monthly BPJS insurance fees and are considered wealthier. However, in practice, the monthly insurance fees for most BPJS cards currently in circulation are paid by the government for people who actually can afford to pay those fees.

Taking into account this situation, the Brebes government must clearly communicate and strictly supervise all village heads to attest that the cardholder is needy (SKTM) as it is the main condition for receiving non-fee BPJS cards. In addition to the weakness of data collection found in Brebes, there is a tendency among people to declare themselves poor in order to benefit from a free service. This cultural poverty is triggered by the high cost of healthcare services and the existence of the BPJS program leading even the wealthiest people, who are generally more aware of the importance of healthcare, to claim to be poor to get free help from the government.

The main problem faced in the Brebes district when registering its citizens is the absence of up-to-date data. The weakness of current data collection has resulted in a targeted misuse of healthcare aid and a difficulty in identifying school students' poverty level. This observation explains the fact that the local Research and Development Office (Bappelitbangda) has initiated a new research called Community-Based Development Information System (SIPBM), which is more accurate than the census-based BPS data. This data is planned to be used to address the issue of healthcare and education assistance, and to ensure general efforts are on target.

Although the Brebes government is open to accommodate complaints, inputs, and suggestions from the community through NGOs and CBOs by means of discussions, our analysis indicates that the characteristics of top-down political 
communications are still inextricably present. It is not surprising that in the end many demonstrators have not been satisfied with the results of very normative discussions, especially with regard to the welfare of teachers and farmers. One of the most democratic and informal channels of communication was born in the form of "teapot cafés» known as cipok (moci and gepok): an open and free means of political communication to seek understanding between the people and the Brebes government. Interestingly, the cipok is performed in tea booths that violate the central government's policy on public space regulated in Law No. 26/2007 on the "Use of space in Indonesia," where sidewalks, among others, should not be used for selling. However, in Brebes, sidewalks (public space) have become part of the public sphere, where people can express their aspirations and interests freely, openly, and informally by discussing and finding solutions with representatives of the Brebes government. This also shows that communicationbased communication channels do not work in Brebes.

\section{Conclusion}

Based on the findings collected from the field and the discussion above, it can be concluded that the Brebes government has not fully implemented all central and district government policies related to public sphere. Specifically, when the public sphere does not take into account the humanitarian development, a number of social interests related to resources and infrastructure cannot be accommodated. As a result, poverty alleviation programs cannot change the state of society. This can be seen from failed efforts of the Brebes government, despite its commendable initiatives and work over the past three years to alleviate poverty. The Brebes district has not yet utilized the potential of IT as a means of communication between citizens and its local government. Thus, the poverty alleviation program in Brebes still leaves a number of temporal (historical background), structural (policy and procedures) and cultural (mental and communication characteristics) challenges, which makes it difficult for Brebes to reach its objective.

\section{Recommendations}

Based on the results mentioned in the Discussion and Conclusion sections, several recommendations can be made as follows:

With regard to political parties, many poverty alleviation programs in Brebes were initiated by the central government. Officially, the Brebes government formulated an integrated poverty alleviation program since the government is supported by most political parties. Firstly, this program is to develop a 
cross-integrated poverty planning strategy under the coordination of the Poverty Alleviation Section. Secondly, it is to move the Poverty Alleviation Section from the jurisdiction of the Regional Secretary Assistant of the Government and Social Sector to that of the district head.

Public services related to poverty alleviation - even if not directly related, such as the procurement of business permits or land certification for farmershave left two major problems. Firstly, a number of corrupt government employees have taken advantage of non-transparent procedures. This issue requires strict law enforcement and government commitment together with police action to curb corruption. Secondly, a number of public service procedures are not transparent. To address the problem, various procedures must be corrected immediately using technology information (online procedure).

Regarding associations, various demonstrations demanding the improvement of farmers' welfare and a sharp increase of teachers' salaries indicate a problem. The Brebes government must be more proactive in cooperating with NGOs concerned about welfare. It must establish active informative communication through effective channels, hearings, and dialogue to collaborate in finding solutions to poverty in Brebes.

As to the education issue, the main problem in Brebes is the limited funding provided by the central government. Three actions can be taken to address this matter. Firstly, the Brebes government can proactively and creatively look for educational funding assistance from the private sector or, as the case may be, from stakeholders outside the district and abroad. Secondly, it can increase the district income by focusing on the economic development of Brebes. Thirdly, the local government can seek to prioritize poverty alleviation within its budget.

Concerning the universal health coverage, it is a very difficult objective to meet in Brebes. Due to the lack of funding, limitations must be made for individuals who can afford their health insurance fees. Restrictions can also be added by limiting insurance coverage to more serious illnesses. Individuals would be able to purchase broader coverage through a premium insurance with strictly monitored procedures and with contributions equivalent to a private health insurance.

In dealing with welfare, assistance should be more appropriately given following disasters. Additionally, help for the poor in Brebes would be more effective through the distribution of staple food, as opposed to cash. Indeed, while the poor are clearly in dire need of cash as well, it must be ensured that food requirements are first met following catastrophes.

To promote the sustainability of self-help groups in Brebes, urban planning needs to take into account the needs of small traders, in particular to find mutually satisfying solutions to the use of sidewalks by these traders, which include 
allocating them in specific and strategic trading places. Other events such as occasional or seasonal markets could provide a profitable sales space for small traders, in addition to attracting non-locals and tourists to travel to Brebes.

In relation to the media aspect, official face-to-face dialogue forums are held regularly and communication technology is used. To increase its effectiveness, the Brebes government needs to ensure the further development of two-way public information channels, including the use of monitored social media or discussion forums.

\section{References}

Aubin, F. (2014). Between Public Space(s) and Public Sphere(s): An Assessment of Francophone Contributions. Canadian Journal of Communication, 39, 89-16. doi: https://doi.org/10.22230/cjc.2014v39n1a2713

Baiocchi, G., Heller, P., and Silva, M. K. (2011). Bootstrapping Democracy Transforming Local Governance and Civil Society in Brazil. California: Stanford University Press.

Bakti, A. F. (2013). Raising Public Consciousness about the Importance of Freedom of Expression in a Democratic Society and on Enhancing the Quality of Life of the Ordinary Citizen: The Case of Indonesia. The Journal of Development Communication, 1(24), 1-14.

Bakti, A. F. (2004). Communication and Family Planning in Islam in Indonesia: South Sulawesi Muslim Perceptions of a Global Development Program. INIS, LeidenJakarta, 2004.

Castells, M., and Himanen, P. (2002). The Information Society and the Welfare State. New York: Oxford University Press.

Castells, M. (2004). The Network Society: A Cross-cultural Perspective. Cheltenham UK: Edward Elgar.

Cohen, J., and Arato, A. (1992). Civil Society and Political Theory. Cambridge, MA: Massachusetts Institute of Technology.

Ishida, T. (2017). Digital City, Smart City and Beyond. International World Wide Web Conference Committee.

Janoski, T. (1998). Citizenship and Civil Society: A Framework of Rights and Obligations in. Liberal, Traditional, and Social Democratic Regimes. Cambridge University Press.

Mclver, W. J. (2004). Global Perspectives on the Information Society. In Brennan, L. L., and Johnson, V. E. (Eds.), Social, Ethnical, and Policy Implications of Information Technology. USA: Information Science Publishing, pp. 1-28.

Nam, T., and Pardo, T. A. (2011). Conceptualizing Smart City with Dimensions of Technology, People, and Institutions. The Proceedings of the 12th Annual 
International Conference on Digital Government Research. Retrieved from https://inta-aivn.org/images/cc/Urbanism/background\%20documents/ dgo_2011_smartcity.pdf

Ostrom, E. (2011). Background on the Institutional Analysis and Development Framework. Policy Studies Journal, 39(1), 7-27. doi: https://doi.org/10.1111/ j.1541-0072.2010.00394.x

Van Dijk, J. (2005). The Deepening Divide: Inequality in the Information Society. London: Sage Publication.

Washburn, D., Sindhu, U., Balaouras, S., Dines, R. A., Hayes, N. M., and Nelson, L.E. (2010). Helping CIOs Understand "Smart City" Initiatives: Defining the Smart City, Its Drivers, and the Role of the CIO. Cambridge, MA: Forrester Research, Inc. Retrieved from http://public.dhe.ibm.com/.

Webster, F. (2006). Theories of Information Society ( $3^{\text {rd }}$ ed). New York: Routledge. 